\title{
Hindsight: providing an easy diagnosis for a rare presentation
}

\author{
Patrick Simon Edward Hayle, ${ }_{1}^{1}$ David Butterworth, ${ }^{2}$ Magdi Hanafy ${ }^{3}$
}

${ }^{1}$ Postgraduate Department, Mid-Cheshire Hospitals Trust, Crewe, UK

${ }^{2}$ Mid-Cheshire Hospitals Trust, Crewe, UK

${ }^{3}$ Department of General Surgery, Mid-Cheshire Hospitals Trust, Crewe, UK

\section{Correspondence to} Dr Patrick Simon Edward Hayle, patrick.hayle@nhs.net

Accepted 5 March 2015

\section{DESCRIPTION}

A 79-year-old woman presented as a surgical emergency with large bowel obstruction. Over the previous 6 months, she had been admitted on two occasions with acute cholecystitis which was treated conservatively with intravenous antibiotics. During these admissions, imaging confirmed the presence of a large solitary gallstone within the gallbladder and plans for a laparoscopic cholecystectomy were made. On this admission to the surgical unit, CT imaging demonstrated large bowel obstruction at the level of the sigmoid colon and pneumobilia was noted (figure 1). No previous attempts at endoscopic retrograde cholangiopancreatography (ERCP) had been made and previous imaging had not identified pneumobilia. An emergency

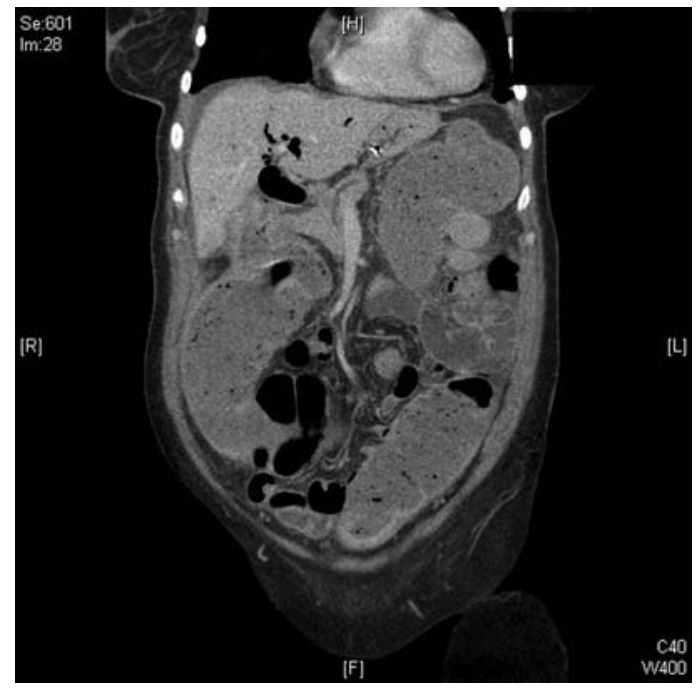

Figure 1 Large bowel obstruction and air in the biliary tree.

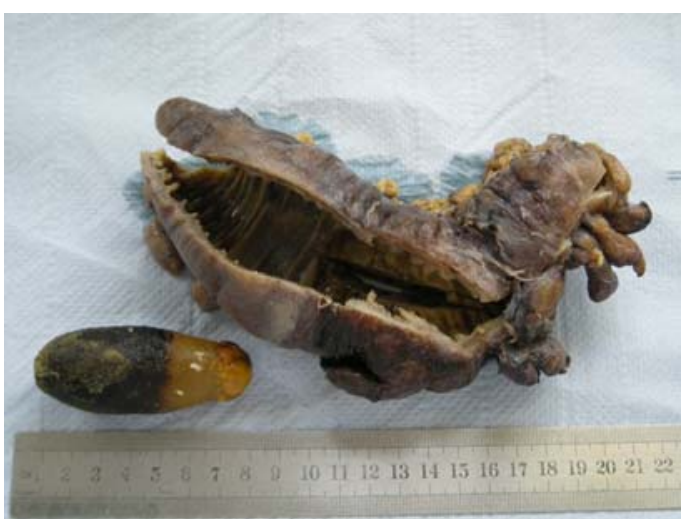

Figure 2 Sigmoid colon containing gallstone.

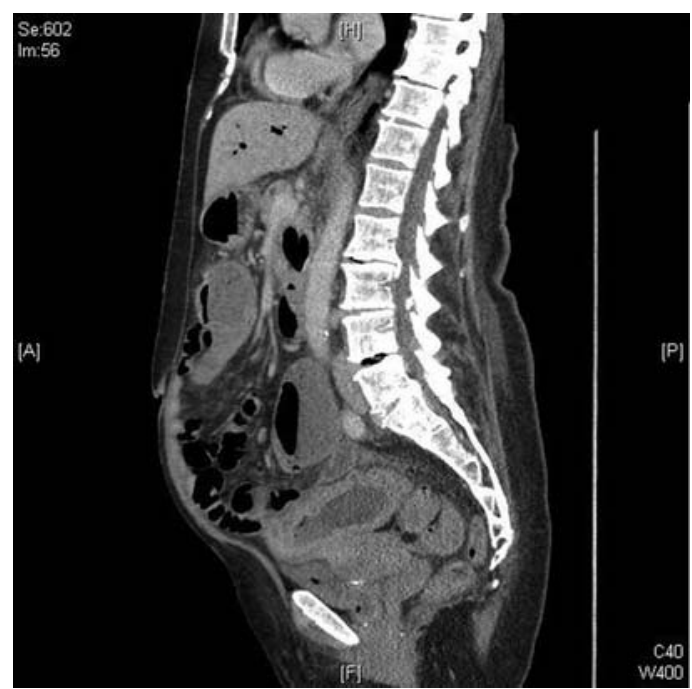

Figure 3 Ovoid structure lying within sigmoid colon.

Hartmann's procedure was performed and pathological examination of the resected specimen revealed a large gallstone impacting into a diverticular stricture, causing obstruction (figure 2). A successful reversal of Hartmann's was performed 6 months later using an open approach.

The aetiology of large bowel obstruction was not clearly demonstrated on preoperative imaging, however with hindsight, the presence of a gallstone in the sigmoid colon can be identified (figure 3). This missed diagnosis meant that less invasive approaches, such as endoscopic retrieval of impacted gallstones or endoscopic electrohydraulic lithotripsy, could not be employed to dislodge and remove the impacted gallstone. ${ }^{1}$ In the absence of these options, even laparotomy and enterolithotomy could have achieved a satisfactory solution to the large bowel obstruction. Thereby avoiding the necessity of a temporary end colostomy and the further psychological impact of a second laparotomy and stoma reversal.

\section{Learning points}

- It is critical that a detailed medical history is taken from all patients and previous investigations reviewed prior to definitive management decision to ensure that both common and unusual differential diagnoses are considered.

Butterworth D, Hanafy M BMJ Case Rep Published online: [please include Day Month Year] doi:10.1136/ bcr-2014-203775
- Always think 'outside the box' when formulating a list of differential diagnoses as rare events do happen. 
Contributors PSEH was responsible for planning, writing and submitting this manuscript. MH supervised the submission of this paper. DB identified the pathology specimen and provided the photographs used in this manuscript.

\section{Competing interests None.}

Patient consent Obtained.
Provenance and peer review Not commissioned; externally peer reviewed.

\section{REFERENCE}

1 Zielinkski MD, Ferreira LE, Baron TH. Successful endoscopic treatment of colonic gallstone ileus using electrohydraulic lithotripsy. World I Gastroenterol 2010;16:1533-6.

Copyright 2015 BMJ Publishing Group. All rights reserved. For permission to reuse any of this content visit

http://group.bmj.com/group/rights-licensing/permissions.

BMJ Case Report Fellows may re-use this article for personal use and teaching without any further permission.

Become a Fellow of BMJ Case Reports today and you can:

- Submit as many cases as you like

- Enjoy fast sympathetic peer review and rapid publication of accepted articles

- Access all the published articles

- Re-use any of the published material for personal use and teaching without further permission

For information on Institutional Fellowships contact consortiasales@bmjgroup.com

Visit casereports.bmj.com for more articles like this and to become a Fellow 